\title{
PELATIHAN PEMBUATAN KOMIK STRIP BAGI GURU: USAHA PENINGKATAN KUALITAS PEMBELAJARAN DI SDN 1 SUMBERARGO
}

\author{
Nine Febrie Novitasari \\ Fakultas Sastra Universitas Abdurachman Saleh Situbondo \\ ninefebrie@gmail.com
}

\begin{abstract}
Good communication and interaction between teachers and students are determinants of success in the teaching and learning process. From the preliminary observation results, teachers at SDN 1 Sumberargo have difficulties in making students active in communicating and interacting with the teachers. Students tend to be passive in communicating for several reasons, such as students who do not get used to speaking in Indonesia, and limited teaching media that can encourage students' interest in communicating. The school is located in a remote that makes it almost impossible to access public facilities. Essentially, teaching media do not need to be modern and sophisticated. The most important thing about teaching media is its usefulness in facilitating students to learn. In this case, a comic strip is an appropriate medium to motivate students to learn to communicate verbally or in writing. These comic strips have a visual element that can attract students' interest. Simple teaching media such as comic strips made by teachers can motivate students to learn to communicate. The teachers can make their comic strips to be used in the learning process. But of course, this requires skills at drawing comic strips. Hence, training on developing comic strips was held to equip skills to teachers at SDN 1 Sumberargo. This activity also aims to provide an alternative teaching media for teachers. Through this training, it is expected that the students will be motivated to start learning to communicate with teachers to increase the quality of education in schools.
\end{abstract}

Keywords: comic strip, communication, SDN 1 Sumberargo, teachers, training.

\begin{abstract}
Abstrak
Komunikasi dan interaksi yang baik antara guru dan siswa adalah salah satu penentu keberhasilan dalam proses belajar mengajar. Dari hasil pengamatan pendahuluan yang telah dilakukan, guru di SDN 1 Sumberargo mengalami kesulitan dalam membuat siswa aktif dalam berkomunikasi dan berinteraksi dengan guru. Siswa cenderung pasif dalam berkomunikasi karena beberapa alasan, seperti siswa yang tidak terbiasa dalam bahasa Indonesia, dan terbatasnya media pengajaran yang dapat mendorong minat siswa untuk berkomunikasi. Sekolah ini terletak di daerah terpencil yang membuatnya hampir mustahil untuk mengakses fasilitas umum. Pada dasarnya, media pengajaran tidak perlu modern dan canggih. Yang terpenting tentang media pembelajaran adalah kegunaannya dalam memfasilitasi siswa untuk belajar. Dalam hal ini, komik strip adalah media yang tepat untuk digunakan untuk memotivasi siswa untuk belajar berkomunikasi secara lisan atau tertulis. Ini karena komik memiliki elemen visual yang dapat menarik minat siswa. Media pengajaran sederhana seperti komik yang dibuat oleh guru dapat memotivasi siswa untuk belajar berkomunikasi. Para guru dapat membuat komik mereka sendiri untuk digunakan dalam proses pembelajaran. Tapi tentu saja ini membutuhkan keterampilan guru dalam menggambar komik. Oleh karena itu, pelatihan pengembangan komik dibuat sebagai solusi untuk membekali guru di SDN 1 Sumberargo. Kegiatan ini juga bertujuan untuk menyediakan media pengajaran alternatif bagi para guru. Melalui pelatihan ini, diharapkan para siswa akan termotivasi untuk mulai belajar berkomunikasi dan berinteraksi dengan guru sehingga kualitas pendidikan di sekolah akan meningkat.
\end{abstract}

Kata kunci: guru, komik strip, komunikasi, SDN 1 Sumberargo, pelatihan 


\section{PENDAHULUAN}

Proses pentransferan pesan dalam proses pembelajaran dapat didukung dengan adanya komunikasi dan interaksi yang baik antara guru dan siswa. Dalam penyampaian materi, pesan yang ingin disampaikan oleh guru disampaikan kepada siswa melalui lisan ataupun tulisan. Namun, proses pembelajaran di SDN 1 sumberargo selama ini tidak dapat berjalan maksimal karena minimnya komunikasi dan interaksi siswa denan gurunya. Permasalahan terbesar adalah banyak siswa yang tidak dapat berkomunikasi dengan bahasa Indonesia secara baik dan benar. Bahasa sehari-hari yang mereka gunakan adalah bahasa Madura. Akibatnya, saat di kelas mereka seringkali pasif saat diajak berkomunikasi dalam Bahasa Indonesia. Letak sekolah yang berada di lokasi terpencil mengakibatkan akses ke sekolah sangat sulit. Terkadang akses ke sekolah ini tidak dapat dilalui saat musim hujan karena jembatan yang menghubungkan ke desa Sumberargo terputus sehingga guru-guru yang berasal dari desa luar tidak dapat masuk untuk mengajar. Hal ini secara tidak langsung mengurasi intensitas komunikasi antara guru dan siswa sehingga kesempatan siswa untuk belajar berkomunikasi semakin kecil. Hal lain yang membuat siswa susah diajak berkomunikasi adalah media ajar yang digunakan sedikit sehingga mereka tidak begitu responsif saat diberikan materi.

Terkait dengan permasalahan tersebut, guru-guru SDN 1 Sumberargo harus mampu membuat satu terobosan baru untuk membuat siswa belajar bagimana cara menyampaikan ide atau gagasan dengan bahasa yang baik. Karya sastra adalah salah satu cara untuk menyampaikan gagasan baik secara lisan, tulis, dan visual. Ada berbagai macam bentuk karya sastra antara lain puisi, novel, cerita pendek, dongeng, legenda, naskah drama, dan komik. Sebagai salah satu bentuk karya sastra, komik ditampilkan dalam bentuk gambar. Secara harfiah, komik adalah kumpulan gambar dan kata-kata yang berurutan (Eisner, 1985). Definisi lain juga diberikan oleh McCloud (1994). Dia menggambarkan bahwa komik terdiri dari gambar yang bertujuan mentransfer informasi atau menghasilkan respons estetika bagi orang yang melihatnya. Dari dua definisi ini, dapat dikatakan bahwa komik adalah sekuens gambar dengan kata-kata yang berfungsi mengirim pesan kepada orang yang membacanya dengan nilai estetika.

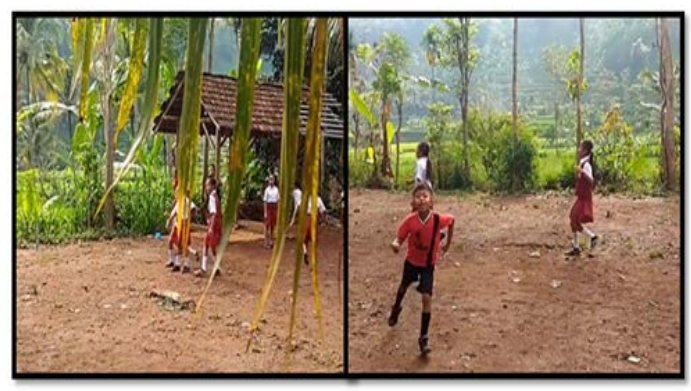

Gambar 1. Halaman SDN 1 Sumberrago

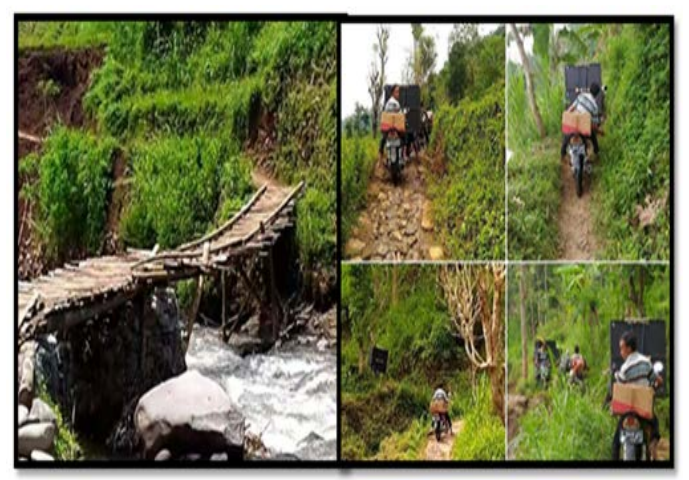

Gambar 2. Akses ke SDN 1 Sumberargo

Pembaca komik mayoritas adalah anak-anak usia sekolah. Karena membaca komik itu menyenangkan, anak-anak biasanya menghabiskan sebagian besar waktu mereka membaca 
komik. Akibatnya, orang tua berpikir bahwa membaca komik hanyalah buang-buang waktu. Dahulu mungkin komik dianggap kurang mendidik karena pembacanya, yang kebanyakan anak-anak, saat membaca komik hanya melihat gambar tanpa membaca. Efek negatif dari membaca komik, seperti peniruan perilaku karakter membuat beberapa orang melarang anak-anak membaca komik. Komik bahkan dipandang sebagai genre sastra yang tidak bermanfaat (Honarvar dan Rahimi, 2011). Ini karena komik dianggap miskin nilai seni dan bahasa. Sedikit yang percaya bahwa membaca komik dapat memberi pengaruh positif pada proses belajar anak.

SDN 1 Sumberargo terletak di daerah terpencil sehingga akses terhadap fasilitas publik sangatlah sulit, termasuk akses untuk mendapatkan media dan bahan ajar. Dikarenakan keterbatasan dalam ketersediaan bahan ajar, baiknya guru-guru di SDN 1 Sumberargo memiliki keterampilan untuk membuat media ajar sendiri. Media ajar tidak perlu mahal dan canggih. Media sederhana asalkan mengena bagi siswa akan lebih bermanfaat. Salah satu media sederhana yang dapat digunakan untuk meningkatkan motivasi siswa untuk berkomunikasi dan berinteraksi dengan guru adalah komik strip. Melalui penggunaan komik strip, siswa akan mudah tertarik dan termotivasi untuk berkomunikasi dalam kelas. Hal ini juga didukung oleh Khalid, Meerah, dan Halim (2010) yang membuktikan bahwa penggunaan kartun dalam komik efektif untuk memicu imajinasi dan kreativitas siswa. Manfaat lainnya adalah melalui penggambaran manusia dan kehidupan dalam karakter kartun, guru dapat mengajarkan pelajaran hidup yang tersirat dalam pembelajaran (Sengul \& Dereli, 2010). Merespon pernyataan yang menyatakan bahwa komik miskin nilai seni dan bahasa, penelitian-penelitian yang telah ada justru membuktikan bahwa penggunaan komik dapat meningkatkan keterampilan berbahasa, baik secara lisan maupun tulisan (Widiseta, 2013; Klau, 2015; Lazarinis dkk. 2015; Humola \& Talib, 2015). Beberapa penelitian tentang komik strip buatan guru juga mendukung bahwa komik strip efektif digunakan sebagai media ajar (Aditya, 2016; Nafiz \& Sapir, 2016)

Namun, guru-guru masih belum memiliki pemahaman yang cukup baik tentang manfaat membuat media ajar sendiri. Mereka juga belum memiliki pandangan tentang penggunaan komik dalam pembelajaran. Lebih jauh lagi, untuk membuat sebuah komik strip, guru perlu diberi keterampilan dalam membuatnya. Mereka harus mengenal karakteristik komik strip, kapan harus menggunakan komik strip, dan bagaimana cara menggunakannya dalam pembelajaran. Dikarenakan permasalahan-permasalahan tersebut, maka kami memberikan solusi yaitu dengan mengadakan pelatihan pembuatan komik strip sebagai media ajar sederhana. Pelatihan ini mencakup pendampingan (tutorial) sampai guruguru menghasilkan komik strip sendiri.

\section{METODE}

Solusi untuk permasalahan yang dialami oleh mitra adalah pemberian keterampilan bagi guru-guru SDN 1 Sumberargo untuk membuat media ajar sederhana berupa komik strip. Pemberian keterampilan akan dilaksanakan melalui serangkaian program pelatihan. Selain memberikan bekal keterampilan membuat komik strip, kegiatan ini juga bertujuan memberikan pemahaman pada guru 
tentang pentingnya media ajar buatan sendiri dan kelebihan penggunaan komik dalam pembelajaran. Termasuk dalam rangkaian pelatihan ini adalah pendampingan bagi guru sampai menghasilkan komik strip yang bisa dipakai dalam proses pembelajaran.

Dalam pelaksanaan kegiatan PKM ini, metode yang diterapkan mencakup dua tahap yaitu tahap pelatihan (tatap muka) dan pendampingan (tutorial). Tahap pelatihan dilaksanakan dalam waktu satu hari selama delapan jam, sedangkan tahap pendampingan (tutorial) diberikan selama lima belas hari. Pada tahap pelatihan, peserta akan mendapatkan materi tentang media ajar dan komik. Nara sumber pada tahap pelatihan adalah kami sebagai tim pelaksana dan satu orang ilustrator yang kami undang untuk memberikan materi tentang komik. Pada tahap pendampingan, peserta harus membuat komik strip yang dapat digunakan dalam proses pembelajaran. Selama tahap ini, peserta juga bebas berkonsultasi dengan nara sumber untuk membantu mereka dalam menyelesaikan komik stripnya.

\section{HASIL DAN PEMBAHASAN}

Seperti yang telah dijelaskan pada bagian metode, kegiatan PKM ini terbagi menjadi dua tahapan yaitu pelatihan (tatap muka) dan pendampingan (tutorial). Tahap pelatihan muka) dilaksanakan pada hari Sabtu, 19 April 2019 di Universitas Abdurachman Saleh Situbondo dari pukul 08:00 - 16:00 WIB. Peserta dari pelatihan ini adalah guru-guru SDN 1 Sumberargo dan beberapa guru dari sekolah lain yang kebetulan berminat untuk mengikuti pelatihan ini. Total peserta adalah dua puluh tiga orang. Tahapan pelatihan (tatap muka) dibagi menjadi tiga sesi: materi dan diskusi, praktikum, dan evaluasi.

\section{Sesi Materi dan Diskusi}

Pada sesi tatap muka, peserta mendapatkan dua materi utama yaitu tentang media ajar dan pembuatan komik. Cakupan materi tentang media ajar meliputi definisi dan jenis media ajar, dan pemanfaatan media ajar. Lebih detail, peserta mendapatkan materi lebih jelas tentang prinsip dasar penggunaan media ajar, kriteria pemilihan media ajar yang baik, kapan harus menggunakan media ajar, dan contohcontoh penggunaan media ajar dalam pembelajaran. Selain itu, peserta juga mendapatkan gambaran lengkap tentang manfaat dan kelebihan media ajar buatan sendiri. Media ajar buatan sendiri akan lebih mengena untuk siswa karena biasanya media ajar tersebut telah didesain sesuai dengan karakteristik siswa. Kebanyakan peserta masih belum memiliki pemahaman yang baik tentang kelebihan media ajar sendiri.

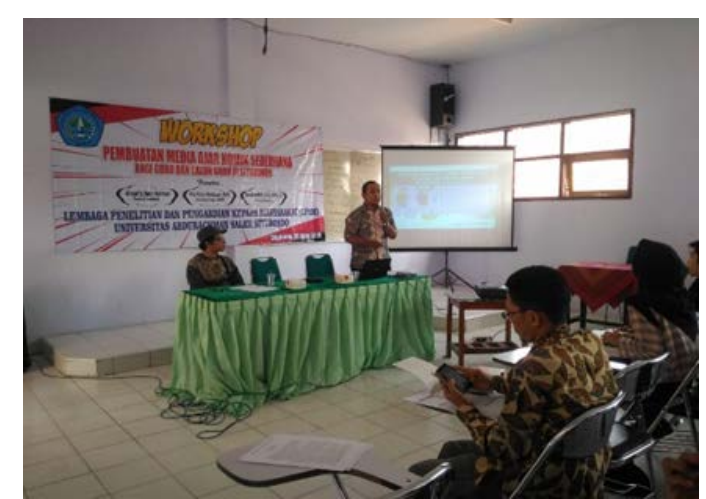

Gambar 3. Pemberian Materi tentang Media Ajar

Materi kedua yaitu materi tentang pembuatan komik. diberikan oleh seorang penulis dan ilustrator asal Situbondo. Pemateri menjelaskan materi tentang komik secara mendetail, mulai dari asal muasal komik, perkembangan komik di Indonesia, 
hingga tata cara membuat komik bagi pemula. Di sini disampaikan apa saja yang harus ada dalam sebuah komik. Elemen-elemen tersebut adalah ide cerita, panel, dialog dan narasi, balon percakapan, dan gambar kartun karakter.

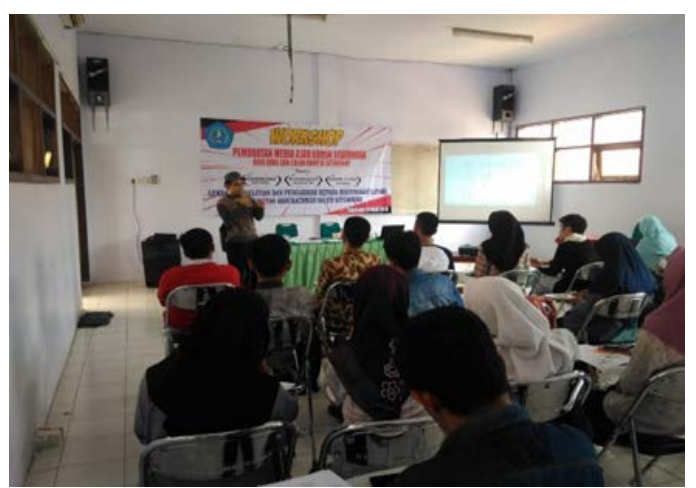

Gambar 4. Pemberian Materi tentang Pembuatan Komik

Dalam tahap ini, peserta tidak hanya diberi materi tentang media ajar dan pembuatan komik. Peserta juga mendapatkan penjelasan dan prosedur penggunana komik strip dalam pembelajaran. Peserta diberi beberapa contoh komik strip yang dipakai di beberapa kelas mata pelajaran seperti Matematika dan Bahasa Indonesia.

Selama pemberian materi, peserta terlihat antusias menyimak dan sangat aktif saat sesi tanya jawab. Hal ini terlihat dari cukup banyaknya peserta yang mengajukan pertanyaan terkait materi yang diberikan.

\section{Sesi Praktik}

Selama sesi praktik, peserta berlatih membuat komik sederhana untuk dipakai dalam proses pembelajaran. Pada awalnya, peserta berlatih memodifikasi komik yang sudah ada. Komik modifikasi ini adalah komik yang sudah ada namun bagian percakapannya telah dihilangkan. Di sini peserta harus mengisi balon percakapan dengan dialog pendek. Hasil karya peserta beragam dan kreatif. Satu persatu peserta menunjukkan hasil kerjanya dan peserta lain harus memberi tanggapan. Berikut contoh modifikasi komik strip karya peserta.

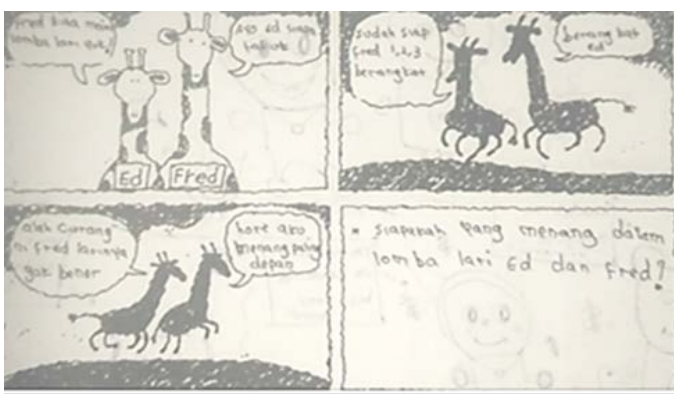

Gambar 5. Contoh Komik Modifikasi Peserta Pelatihan

Setelah dirasa cukup mampu, selanjutnya peserta harus membuat komik sederhana sendiri dengan memperhatikan pemilihan kata dalam pembuatan dialog dan tingkat kerumitan cerita. Selain itu, mereka juga harus melengkapi komiknya dengan beberapa pertanyaan yang bisa dipakai guru untuk diberikan pada siswa terkait isi komik. Gambar di bawah adalah beberapa contoh hasil komik peserta.

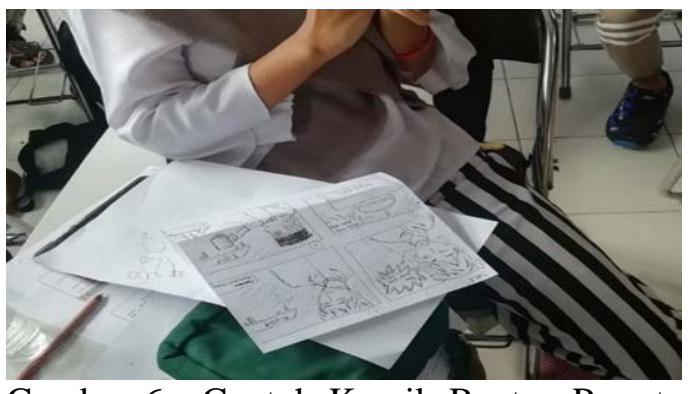

Gambar 6. Contoh Komik Buatan Peserta Pelatihan

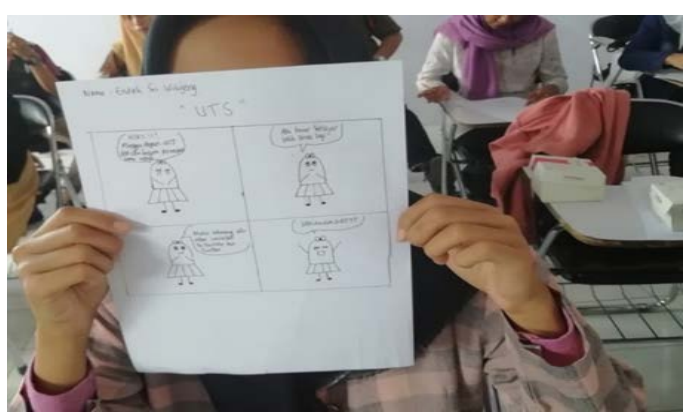

Gambar 7. Peserta Menunjukkan Komik Buatannya Sendiri 


\section{Sesi Evaluasi}

Pada sesi ini pemateri bersamasama dengan peserta mengevaluasi hasil pelatiah hari itu. Terdapat beberapa hal yang dimasukkan pada evaluasi, yaitu:

1. Adanya komik peserta yang memiliki jalan cerita cukup rumit. Sehubungan dengan hal ini, peserta diberi pemahaman bahwa mereka harus memperhatikan tingkat kesulitan isi cerita sesuai dengan level mahasiswa.

2. Tidak adanya jalan cerita yang jelas. Kejelasan alur cerita dalam komik haruslah dapat dibaca oleh pembacanya. Jadi, misalnyapun tanpa dialog atau narasi, jalan cerita haruslah dapat dipahami oleh pembaca.

3. Komik tidak dalam modus naratif. Ada seorang peserta yang menggunakan komik dalam bentuk iklan layanan masyarakat. Terkait hal ini, peserta diberi penjelasan bahwa komik boleh dalam bentuk apapun. Artinya, komik tidak harus berbentuk panel-panel. Tetapi yang harus diingat adalah harus ada nilai edukasi dalam komik tersebut.

$$
\text { 4. Komik tidak boleh }
$$

mengandung unsur SARA. Karena digunakan dalam pembelajaran, isi komik maupun ilustrasi tidak diperkenankan untuk mengandung SARA. Hal ini tidak mencerminkan salah satu prinsip penggunaan media ajar yaitu harus bersifat mendidik.

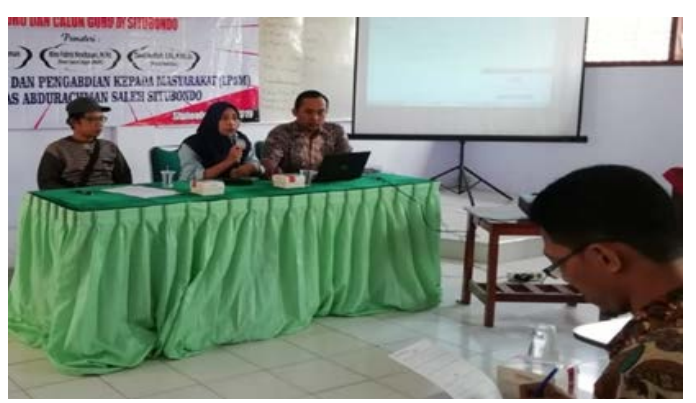

Gambar 8. Sesi Evaluasi

Setelah sesi evaluasi, peserta diberi penjelasan tentang tahapan rangkaian kegiatan selanjutnya, yaitu tahapan pendampingan (tutorial). Peserta diberi waktu lima belas hari untuk merancang komik strip yang bisa digunakan dalam proses pembelajaran. Komik strip tersebut harus dilengkapi dengan sedikit penjelasan tentang prosedur penggunaannya.

Dari tahapan pelatihan (tatap muka) ini, peserta sudah lebih paham tentang media ajar, terutama manfaat media ajar buatan sendiri. Peserta juga telah memiliki cukup informasi tentang pembuatan komik strip dan bagaimana menggunakannya di kelas. Sebelumnya, semua peserta belum pernah mencoba mengajar menggunakan media komik strip. Bagi mereka, pelatihan ini memberikan pengalaman baru yang bisa mereka gunakan nanti sebagai alternatif media ajar yang menarik.

Sesi pendampingan (tutorial) merupakan kelanjutan dari tahap tatap muka. Tahap ini merupakan tugas rumah bagi peserta untuk membuat komik strip yang benar-benar dapat dipakai dalam proses pembelajaran. Tahap tutorial diadakan selama lima belas hari dari tanggal 20 April - 4 Mei 2019. Selama tahap ini, peserta boleh berkonsultasi dengan pemateri dalam proses pembuatan komiknya. Penilaian dari tahap tutorial mencakup penyusunan ide cerita, panel cerita, dialog dan narasi, pengilustrasian tokoh cerita, dan tahap penyelesaian komik. Beberapa hal yang didiskusikan oleh peserta dengan nara sumber adalah cara membuat pertanyaan terkait komik strip, jumlah panel yang boleh dibuat, dan sistem pewarnaan. Peserta boleh menggambar komiknya secara manual menggunakan pensil, spidol, dan alat pewarna lainnya, dan juga boleh menggunakan aplikasi komputer. Hasil karya peserta dikirimkan ke panitia dalam format .jpg dan harus dilengkapi dengan sedikit informasi tentang 
konteks penggunaanya. Namun, dari total dua puluh tiga peserta hanya dua belas orang yang mengirimkan hasil karyanyagambar di bawah adalah beberapa contoh komik strip kiriman peserta.
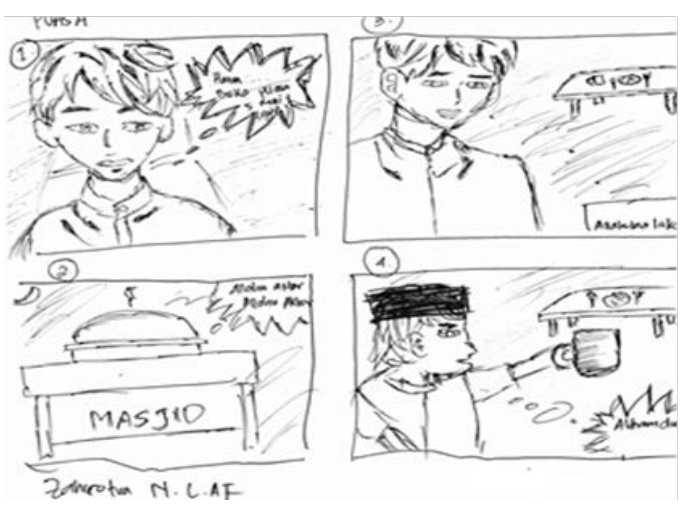

Gambar 9. Komik Karya Peserta (1)

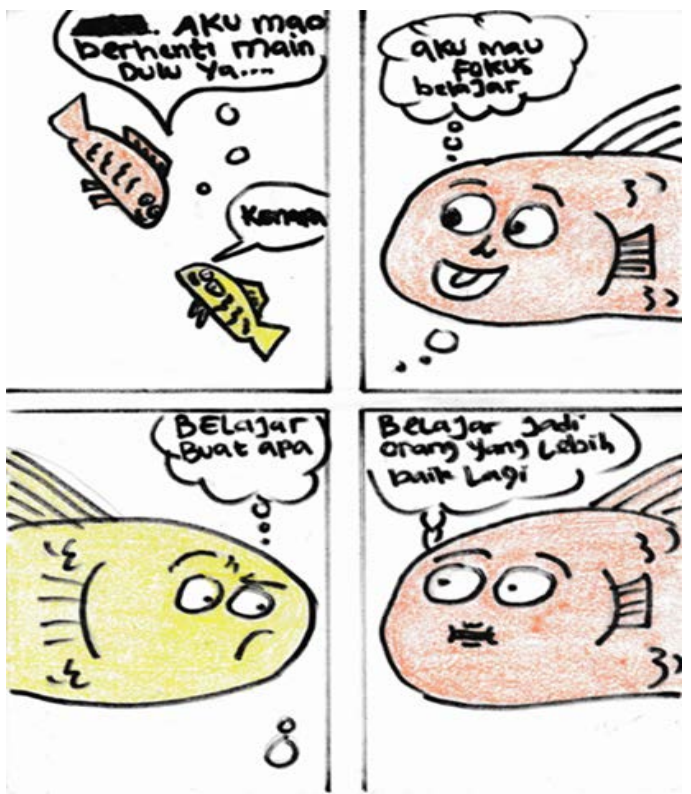

Gambar 10. Komik Karya Peserta (2)

Hasil dan luaran dari serangkaian kegiatan PKM ini adalah adanya peningkatan pemahaman guru tentang media ajar, khususnya buatan sendiri, adanya pemahaman guru tentang penggunaan komik strip sebagai media ajar, peningkatan kualitas dan profesionalisme guru, dan adanya alternatif variasi media ajar bagi siswa untuk meningkatkan keterampilan berkomunikasi. Bila dirangkum, hasilnya adalah seperti yang tertera di Tabel 1.

Tabel 1. Hasil dan Luaran Kegiatan

\begin{tabular}{|l|c|c|}
\hline \multicolumn{1}{|c|}{ Luaran yang Ditargetkan } & Tercapai & $\begin{array}{c}\text { Belum } \\
\text { Tercapai }\end{array}$ \\
\hline $\begin{array}{l}\text { Peningkatan pemahamanan } \\
\text { guru tentang manfaat dan jenis } \\
\text { media ajar }\end{array}$ & $\sqrt{ }$ & \\
\hline $\begin{array}{l}\text { Peningkatan pemahamanan } \\
\text { gur tentang penggunaan } \\
\text { komik strip dalam } \\
\text { pembelajaran }\end{array}$ & $\sqrt{ }$ & \\
\hline $\begin{array}{l}\text { Peningkatan kualitas dan } \\
\text { profesionalisme guru }\end{array}$ & $\sqrt{ }$ & \\
\hline $\begin{array}{l}\text { Dihasilkannya media ajar } \\
\text { komik sederhana buatan guru }\end{array}$ & $\sqrt{ }$ & \\
\hline
\end{tabular}

\section{SIMPULAN}

Kesimpulan yang dapat ditarik dari adanya serangkaian kegiatan pelatihan dan pendampingan pembuatan media ajar berbentuk komik strip membuktikan bahwa kegiatan ini efektif dalam memberikan guru keterampilan membuat alternatif media ajar buatan sendiri yaitu komik strip. Dengan keterampilan menggambar komik strip yang dimiliki, walaupun dengan alat sederhana seperti pensil atau spidol dan selembar kertas guru sudah dapat membuat sebuah komik strip. Tidak butuh teknologi yang canggih untuk membuatnya. Maka dari itu, sifat praktis dari komik strip memudahkan guru dalam membuat media ajar. Dengan adanya komik strip buatan guru, permasalahan awal di sekolah mitra dimana siswanya kurang aktif dalam berkomunikasi dan berinteraksi dengan guru dapat segera teratasi sehingga akan dapat meningkatkan kualitas pembelajaran dan pendidikan.

\section{UCAPAN TERIMA KASIH}

Pelaksana kegiatan mengucapkan terimakasih kepada pihak-pihak yang telah membantu 
terlaksananya kegiatan ini. Terimakasih kami sampaikan kepada P3M Universitas Abdurachman Saleh Situbondo yang telah mendanai kegiatan ini. 2.SDN 1 Sumberargo sebagai mitra kegiatan. Ahmad Sufiatur Rahman sebagai nara sumber kegiatan pelatihan.

\section{DAFTAR PUSTAKA}

Aditya, M. A. M. (2016) 'Pengembangan media komik untuk pembelajaran teks deskripsi berdasarkan kurikulum 2013 di kelas VII SMP Pangudi Luhur 1 Klaten tahun pembelajaran 2015/2016'. Sanata Dharma University. Available at: https://repository.usd.ac.id/467 6/2/101224064_full.pdf.

Eisner, W. (1985) 'Comics \& Sequential Art.pdf', Tamarac (Florida), p. 164. Available at: https://books.google.com/book s?id=b3rxmP4Lzj0C\&pgis=1 \%5Cnhttp://thepiratebay.se/torr ent/4617697/Will_Eisner_Theo ry_of_Comics_Sequential_Art. pdf.

Honarvar, H. and Rahimi, A. (2011) 'Surveying techniques for cultural problems of children comic strips translation', Procedia - Social and Behavioral Sciences. Elsevier B.V., 28, pp. 1076-1078. doi: 10.1016/j.sbspro.2011.11.194.

Humola, Y. and Talib, R. (2015) 'Enhancing The Students Writing Ability by Using Comic Strip: An action research conducted at the tenth grade of SMA Negeri I Tapa', in ICTTE FKIP UNS 2015, pp. 614-623.
Khalid, H., Meerah, T. S., \& Halim, L. (2010). Teachers' perception towards usage of Cartoon in teaching and learning physics. Procedia - Social and Behavioral Sciences, 7(2), 538-545. https://doi.org/10.1016/j.sbspro .2010.10.072

Klau, Renyfa Okfiani. (2015) using comic strips to improve the speaking skills of Grade VIIstudents of SMPNn 15 Yogyakarta in the Academic year of 2013/ 2014. State University of Yogyakarta. Available at: http://eprints.uny.ac.id/25531/1 /Renyta\%20Okfiani\%20Klau_ Thesis\%20complete.pdf

Lazarinis, F. et al. (2015) 'E-comics in teaching: Evaluating and using comic strip creator tools for educational purposes', 10th International Conference on Computer Science and Education, ICCSE 2015, (July), pp. 305-309. doi: 10.1109/ICCSE.2015.7250261.

McCloud, S. (1994) 'Understanding comics by Scott McCloud | LibraryThing'. Available at: http://www.librarything.com/w ork/6084\&book=15607697.

Nafis, Z. F. N. and Sapir (2016) 'Pengembangan media pembelajaran komik audio visual bagi pembelajaran Ekonomi materi kurs valuta asing di SMA Negeri 8 Malang', JPE, 9(2), pp. 156164.

Şengül, S. and Dereli, M. (2010) 'Does instruction of "Integers" subject with cartoons effect students' mathematics anxiety?', Procedia - Social and Behavioral Sciences, 2(2), pp. 
MARTABE : Jurnal Pengabdian Masyarakat Vol 4 No 1 Tahun 2021 Hal 258-267

2176-2180. doi:

10.1016/j.sbspro.2010.03.302.

Widiseta, D. (2016) 'The Effectiveness

of Using Comic Strips in

Improving the Students'

Writing Descriptive Text. State

University of Yogyakarta.

Available

at:

http://eprints.uny.ac.id/25700/1

/Damar Widiseta

07202244050.pdf. 